\title{
The increasing global environmental consequences of a weakening US-China crop trade relationship
}

\author{
Guolin Yao ${ }^{1 凶}$, Xin Zhang $\oplus^{1 凶}$, Eric A. Davidson $\oplus^{1}$ and Farzad Taheripour ${ }^{2}$
}

The consideration of tariffs on China's imports of US agricultural products has focused on economic impacts, while the environmental consequences have received less attention. Here we use a global computable general equilibrium model to evaluate long-term crop portfolio changes induced by China's retaliatory agricultural tariffs and thereby assess the environmental stresses imposed by different crop production portfolios based on region-specific and crop-specific databases. We show that China's tariffs cause unintended increases in nitrogen and phosphorus pollution and blue water extraction in the United States as farmers shift from soybeans to more pollution-causing crops. If diverted to Brazil, China's soybean demands would reduce Brazilian stresses of nitrogen pollution and water use through crop portfolio changes, but may add additional pressures on phosphorus pollution and deforestation. On a global scale, trade policies could help to reduce nutrient pollution and water source depletion by promoting crop production where it is most efficient in terms of nutrient and water use.

hina consumed US $\$ 19.6$ billion of US agricultural exports in 2017, making it one of the top agricultural markets for the United States ${ }^{1}$. Of these US agricultural exports, $86 \%$ were crop products, of which $74 \%$ were soybeans ${ }^{2}$. China's retaliatory tariffs on US agriculture have directly affected the incomes of US farmers ${ }^{3-5}$. In 2018, China's retaliation led to a sudden drop in China's total agricultural imports from the United States by about US\$10 billion ${ }^{6}$, especially soybeans ${ }^{2}$. However, little attention has been paid to the environmental consequences of such uncertain trade relationships, which will, in turn, affect the socioeconomic welfare of farming communities and downstream communities and ecosystems.

The weakening agricultural US-China trade relationship potentially has profound environmental consequences on the two countries and the world, given the current impacts of crop production. Agriculture demands $70 \%$ of the water used for irrigation worldwide ${ }^{7}$ and is a dominant nutrient polluter. Nitrogen and phosphorus applications to croplands in excess of crop demands are mostly lost to the environment, eventually leaching to water bodies, causing eutrophication, or emitted to the atmosphere as gases that alter climate $^{8-11}$ and impact human health ${ }^{12}$. Potential production shifts among crops and across countries with different resource use efficiencies (RUEs, total product outputs per unit of resource inputs) are likely to change the global, national and local nutrient pollution and water demands.

The RUE of crop production varies among crops and differentiates across countries, due to different production costs, practices and technologies ${ }^{13}$. International trade enables the reallocation of crop production from resource-inefficient regions (for example, China) to resource-efficient regions (for example, the United States $)^{14}$. Through crop imports, China avoided US $\$ 22 \pm 16$ billion of nitrogen pollution damage costs in $2015^{15}$. In contrast, monetized estimates of the costs of excessive nitrogen pollution from US agriculture range from US\$59 billion to US $\$ 340$ billion per year ${ }^{16}$ close to or higher than the US $\$ 68$ billion value of total US crop export revenues in $2017^{2}$. Subsequent crop shifts due to US-China trade tensions could also spill over to the rest of the world through trade flows-opening up opportunities for South America to significantly increase its share of China's market ${ }^{3,17}$, potentially boosting the continent's fertilizer use and cropland expansion. Therefore, it is critical to evaluate the global environmental consequences of potential US-China crop trade tensions beyond economic welfare impacts, especially the effects on water use and nutrient (that is, nitrogen and phosphorus) pollution driven by crop shifts ${ }^{18}$. Of the economic studies on US-China trade tensions, some have evaluated land use change, terrestrial $\mathrm{CO}_{2}$ emissions and deforestation ${ }^{19-21}$, but few have examined water use and nutrient pollution.

Here we present an evaluation of the impacts of US-China crop trade tensions on nutrient pollution and blue water demand in the two countries and the world, considering both market-mediated responses and crop portfolio changes ${ }^{22-24}$. We employed a computable general equilibrium model (CGE, which refers to models that capture economy-wide market-mediated factors and have been widely used to assess trade policy impacts on economic activities ${ }^{3,17,25-28}$ ), GTAP-BIO, to evaluate long-term crop portfolio changes induced by China's retaliatory agricultural tariffs (Methods and Supplementary Information, section 1$)^{3}$. We then assessed the environmental stresses imposed by different crop production portfolios with region-specific and crop-specific databases for three major environmental stressors: nitrogen surplus and phosphorus surplus (see detailed definition in Methods) to evaluate potential nitrogen and phosphorus losses to the environment, and blue water demand-the surface and ground water that could be used for irrigation-to assess water use ${ }^{13,15}$. To validate the robustness of the result, we performed sensitivity analyses on the database of environmental stressor intensity and key model parameters. Based on the modelled crop portfolio changes in 18 agroecological zones (AEZs) (Supplementary Fig. 2), we downscaled the environmental assessments to the subnational (grid) level to investigate the potential heterogeneous impacts of trade policies on subnational scales

${ }^{1}$ Appalachian Laboratory, University of Maryland Center for Environmental Science, Frostburg, MD, USA. ${ }^{2}$ Department of Agricultural Economics,

Purdue University,West Lafayette, IN, USA.凶e-mail: guolin.yao523@gmail.com; xin.zhang@umces.edu 


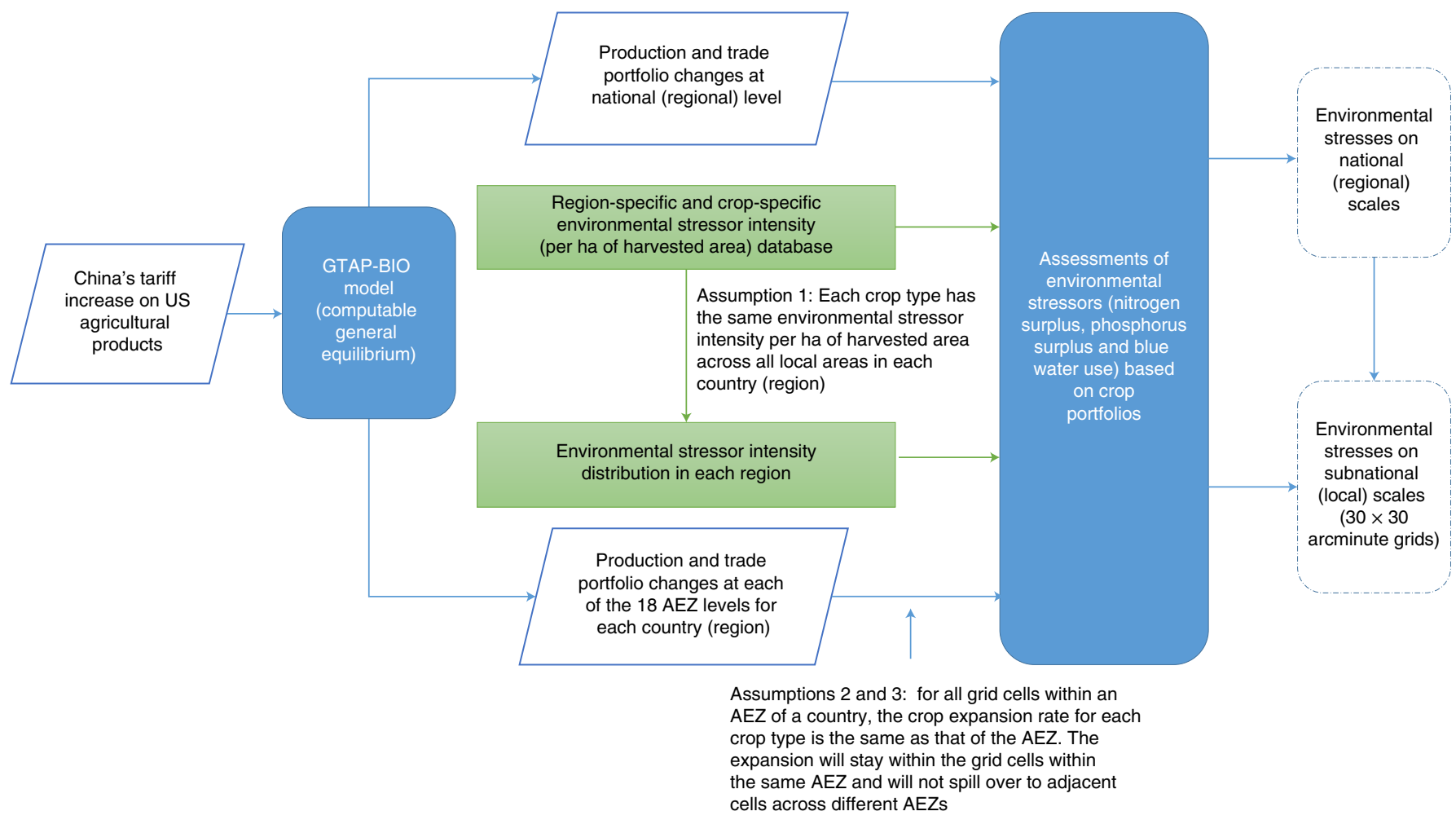

Fig. 1 | Schematic flow of environmental stressor evaluation. The blue rounded squares represent the model. Parallelograms represent the inputs and outputs of the GTAP-BIO model. Green rectangles are the base data used to assess the environmental stressors. Rounded squares with dotted lines are environmental stresses assessed. The arrows represent the data flows of the model structure.

and to identify the environmental degradation hotspots that require policy attention. Figure 1 presents a schematic overview of the environmental stressor evaluation. Finally, we discuss the policy implications of our results as well as the ongoing events and policies that could lead to severe environmental consequences.

\section{Results}

The environmental stresses of existing US-China crop trade. In the past, producing the volumes of crops demanded by China exacerbated US environmental pressures, but potentially relieved the environmental stresses on China and the world. In 2014-2016, on average, to produce the crops exported to China, the United States devoted an additional $12 \mathrm{Mha}$ of harvested area, demanded 4 trillion litres $\left(1\right.$ trillion $\left.=1 \times 10^{12}\right)$ more blue water, and increased nitrogen and phosphorus surplus by $0.5 \mathrm{TgN}\left(1 \mathrm{Tg}=1 \times 10^{9} \mathrm{~kg}\right)$ and 0.007 TgP (Fig. 2). In contrast, if China's crop imports from the United States were produced in China domestically with its current technology and management practices, assuming adequate resources and suitable climates and soil conditions, it would require nearly 20 Mha harvested area and 9 trillion litres of blue water, and would lead to nitrogen and phosphorus surpluses of $1.7 \mathrm{TgN}$ and $0.3 \mathrm{TgP}$. Such drastic shifts in the associated environmental stressors would consequently produce a net increased global burden of environmental stresses, including net additional exploitation of $8 \mathrm{Mha}$ of harvested area and 5 trillion litres of blue water, and further losses of $1.2 \mathrm{TgN}$ and $0.3 \mathrm{TgP}$ to the environment.

If China's crop imports from the United States were entirely substituted by imports from other regions of the world, the environmental stressors of the production would vary among regions due to the different production efficiencies and available resources (Fig. 2). For example, to produce the same volume of crops demanded by China, Brazil would require an additional 2 Mha of harvested area and would induce an additional $0.5 \mathrm{TgN}$ surplus and
0.22 TgP surplus, compared with the United States, but would substantially reduce blue water demands. Other South American countries would be a less-polluting alternative to the United States given the region's more efficient nitrogen use and blue water demand, but higher costs and limited resource availability may impede them from replacing the crop supply from the United States entirely ${ }^{17}$. Overall, this comparison suggests that the current production reallocations from China to the United States achieved through international trade have relieved environmental burdens for China and the world due to China's relatively low efficiencies in both water use and fertilizer use compared with the United States and the rest of the world. Admittedly, this comparison with Brazil and other South American countries demonstrates an extreme case of production reallocations from the United States to the rest of the world, and such reallocation is likely to be buffered by market-mediated responses and considerations of biophysical limits; however, it demonstrates the general direction of changes in environmental consequences in the context of weakening US-China crop trade.

The national impacts of the weakening trade relationship. Shifts in crop production portfolios. Under the proposed December 2019 tariff scenario (Table 1), China's retaliatory tariffs would potentially increase the prices of US agricultural products in China's domestic market. This would lower China's demands for US agricultural products, eventually lowering US farmers' income and discouraging them from producing relevant crops $^{3-5}$. Given the fact that over $70 \%$ of China's crop imports from the United States are soybeans, domestic soybean prices in the United States are affected, depressing their production in the United States by about 3 Mha. Crops that are less traded with China would be less affected by China's tariff increase. Hence, over the long term, US farmers would switch to these less-traded crops with China, such as other coarse grains (primarily corn), wheat and other agricultural products. Besides 

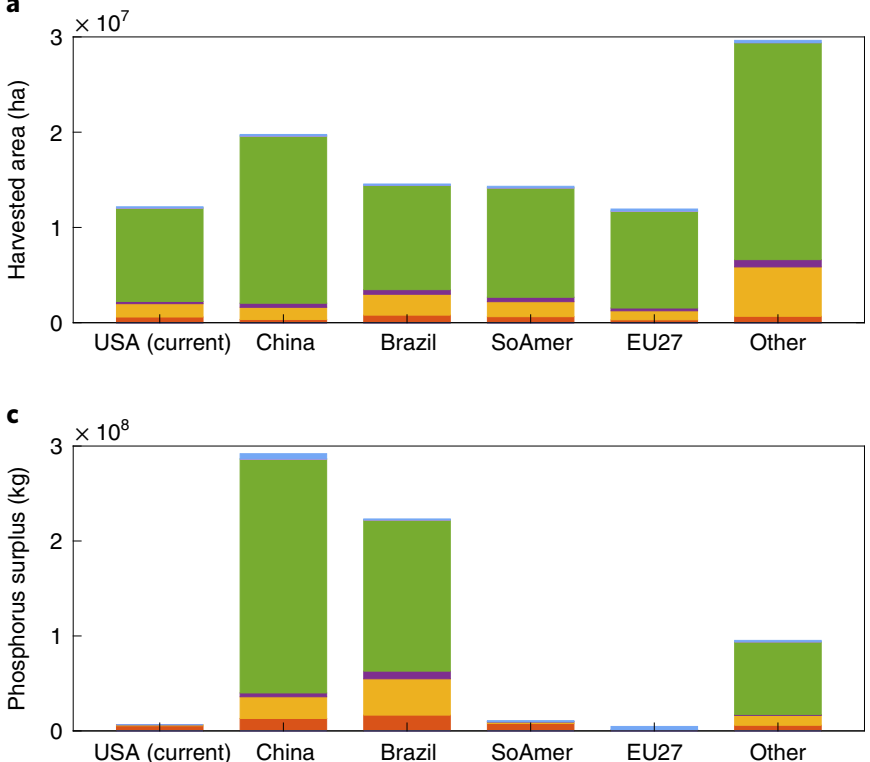

b

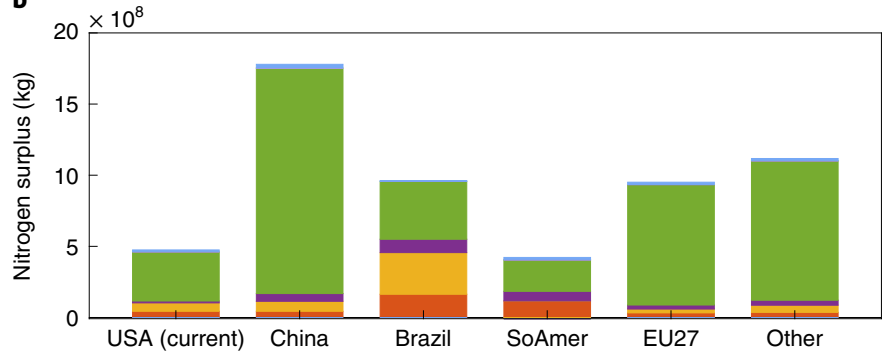

d

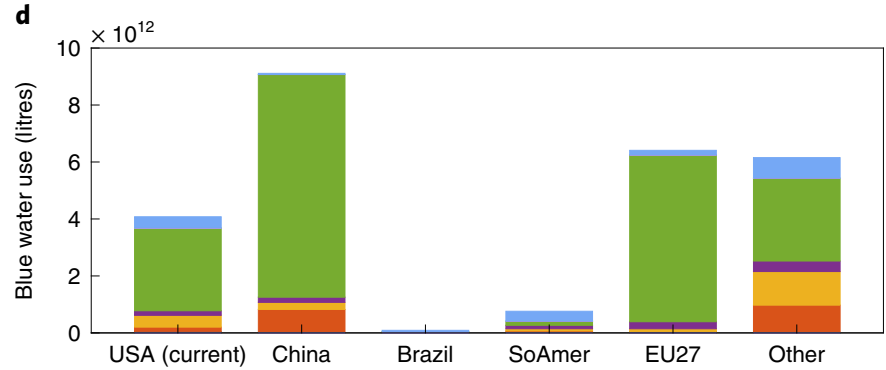

Paddy rice $\quad$ Wheat $\quad$ Sorghum $\quad$ Other coarse grains $\square$ Soybeans

Palm fruit

Rapeseed

Sugar crop OthAgri

Fig. 2 | Environmental stresses affecting crop substitution. a-d, Environmental stresses of producing the average $2014-2016$ crop portfolio China imported from the United States at each region's current RUE levels, given adequate resources and suitable climate and soil conditions: required harvested area (ha) (a), induced nitrogen surplus (kg) (b), phosphorus surplus (kg) (c) and blue water demand (litres) (d). Each coloured bar indicates the environmental stress of each crop type. Only the US bars show the environmental stressors that actually happened. Other regions' bars are the potential environmental stressors that would have happened if those regions had grown the same crops to meet China's demands. For example, in the nitrogen surplus graph (b), the US bar shows that the United States generated a 0.5 TgN surplus when producing the crops exported to China. China's bar in panel b denotes that China would have generated a 1.8 TgN surplus if its entire imported crop portfolio from the United States had been produced domestically. Similarly, if those crops had been grown in Brazil, the potential burdens are shown by the bars for Brazil. SoAmer, South America (apart from Brazil).

soybeans, non-soybean oilseeds are also among the major crops that China imports from the United States. Under the defined scenario, non-soybean oilseeds are also retaliated, and their production thus contracts in the United States by $0.6 \mathrm{Mha}$. As a result, the total harvested area in the United States would decline by $1.25 \mathrm{Mha}$.

Relatively lower-priced soybeans from Brazil and other South American countries, due to the absence of tariffs, would incentivize China's soybean imports from these countries. China's rising demands would increase the income of soybean farmers and motivate soybean expansion in Brazil and other South American countries by 3 and $0.8 \mathrm{Mha}$, respectively, adding pressures to their cropland expansion ${ }^{19-21}$. China's retaliation on US soybeans would spur China's domestic oilseed production in general by $0.5 \mathrm{Mha}$. However, with intensified agricultural production and limited harvested area expansion capabilities, China would experience limited changes in its crop portfolio and harvested area. As soybean is the major protein source for livestock animals ${ }^{29}$, tariffs on meat could further disincentivize US soybean production. Since South America mainly competes with the United States in China's domestic soybean market, the production of all non-soybean crops in South America would experience limited incentives.

Changes in environmental stresses. Shifts in crop portfolios are accompanied by changes in environmental stressors such as nitrogen surplus, phosphorus surplus and blue water demand. Although the total harvested area in the United States would contract by 1.25 Mha, its total nitrogen surplus (expressed as $\mathrm{kgN}$ ) would increase by 35 million $\mathrm{kgN}$ as soybean, a nitrogen-fixing crop with relatively high nitrogen-use efficiency (NUE) and low nitrogen surplus intensity (expressed as $\mathrm{kgNha}^{-1}$ ), shifts to other crops (Fig. 3). The reduction of 105 million $\mathrm{kgN}$ surplus due to soybean contraction in the United States is less than the additional nitrogen surplus generated by the expansion of other crops, such as other coarse grains, with higher nitrogen surplus intensity. In contrast, Brazil and other South American countries would reduce their nitrogen surplus by 119 million $\mathrm{kgN}$ and 81.5 million $\mathrm{kgN}$ owing to substitutions of soybean for other non-soybean crops. Globally, the nitrogen surplus increase in the United States is offset by the nitrogen surplus decline in Brazil as a result of the soybean shifts from the United States to Brazil to meet demands of China. Overall, global nitrogen surplus would significantly decline by 154 million $\mathrm{kgN}$ due to the contractions of nitrogen-inefficient crops (for example, other coarse grains, wheat, sugar crops and other agricultural products) in South America, and their increase in the United States, where they can be grown more efficiently and with lower nitrogen surplus intensity.

The contraction of the harvested area in the United States would not lead to any reduction in blue water demand. If soybean alone is subject to China's retaliation, the US blue water demand would increase substantially by 1.6 billion litres (Supplementary Information, section 9 and Supplementary Fig. 7). In this case, the crops that are projected to increase production in the United States either replace soybean production with higher water demand per harvested area (for example, corn in the 'other coarse grains' category) or tend to expand in the regions with high blue water demand (for example, 'other oilseeds'). However, when non-soybean oilseeds are also retaliated, the increase in US water demands would be only 0.1 billion litres, much lower than that of the soybean-only tariff scenario, as these water-demanding crops also decline in production. Although it is unlikely that farmers will invest significantly for irrigation equipment given a short-term policy or market shock ${ }^{5,30}$, it is possible for farmers to increase irrigation water use on land already equipped with irrigation infrastructure, to shift crop type (for example, from soybean-corn rotation to continuous corn) and perhaps even to invest in new equipment as the 
Table 1 | China's retaliatory tariff percentage increases for US agriculture as of May and December 2019

\begin{tabular}{lll}
\hline GTAP crop types & $\begin{array}{l}\text { Implemented as of 13 } \\
\text { May 2019 (\%) }\end{array}$ & $\begin{array}{l}\text { Proposed for 15 } \\
\text { December 2019 (this } \\
\text { analysis) (\%) }\end{array}$ \\
\hline Soybeans & 24.87 & 33.18 \\
\hline $\begin{array}{l}\text { Other agricultural } \\
\text { products }\end{array}$ & 22.35 & 30.8 \\
\hline $\begin{array}{l}\text { Other oilseeds } \\
\text { Processed food }\end{array}$ & 24.87 & 33.18 \\
\hline $\begin{array}{l}\text { Forestry } \\
\text { Processed }\end{array}$ & 21.65 & 30.03 \\
\hline non-ruminant meat & 44.96 & 9 \\
\hline Rapeseed & 24.87 & 54.88 \\
\hline $\begin{array}{l}\text { Processed ruminant } \\
\text { meat }\end{array}$ & 22.52 & 33.18 \\
\hline Beverage and sugar & 10.76 & 23.5 \\
\hline Sorghum & 24.91 & 11.39 \\
\hline $\begin{array}{l}\text { Processed dairy } \\
\text { products }\end{array}$ & 22.83 & 34.91 \\
\hline Soybean oil & 22.35 & 24.46 \\
\hline Wheat & 24.28 & 30.8 \\
\hline Sour & & 34.28 \\
\hline
\end{tabular}

Source: ref. ${ }^{44}$.

trade tension becomes a norm in the context of growing tensions between the United States and China. Therefore, the reduction of blue water demand for soybean in the United States could be outweighed by the increase in water demand for other crops (Fig. 3d). Under both scenarios, similar patterns are observed on the global scale: global blue water demand would increase because the benefits of blue water savings from shifts in soybeans production (that is, shifts from the United States to Brazil and other South American countries) would be offset by the increasing blue water demand in non-soybean oilseed expansion in water-scarce regions.

Trade-offs and synergies also exist within each region across different environmental stressors. The expansion of soybean, a nitrogen-fixing plant that is relatively more efficient than many other crops, would reduce Brazilian nitrogen surplus by 120 million $\mathrm{kgN}$ but increase its phosphorus surplus by 23.5 million $\mathrm{kgP}$. Brazilian soybean is intensively produced in areas with highly weathered, naturally acidic soils that render much of the native and applied phosphorus unavailable to the crop. Brazilian soybean production thus requires higher phosphorus fertilizer and lime inputs than soybeans produced in most temperate regions ${ }^{31}$. With similar PUE levels, the phosphorus surplus increase due to soybean expansion is higher than the phosphorus surplus decline driven by the contraction of other crops-resulting in a net 23.5 million kgP surplus increase in Brazil. Although most of this phosphorus surplus is currently retained in Brazilian soils, the accumulated phosphorus could eventually reach saturation and pollute water bodies ${ }^{32}$. In addition, the increased demand for phosphorus fertilizer and lime in Brazil may exceed domestic supplies of rock phosphorus reserves and lime. In contrast to Brazil, the United States would suffer from an increase in both phosphorus and nitrogen surplus by 34.7 million $\mathrm{kgP}$ and 10.3 million $\mathrm{kgN}$, respectively, as the production shifts from soybean to more fertilizer-intensive crop types, while other South American countries would experience alleviation in both phosphorus and nitrogen surplus by 81.5 million $\mathrm{kgP}$ and 5 million $\mathrm{kgN}$, respectively, due to the shifts opposite to those in the United States. Global phosphorus surplus would be further aggravated by
30 million $\mathrm{kgP}$ as soybeans are expanded in Brazil where phosphorus use is more inefficient.

Overall, the weakening US-China agricultural trade relationship would worsen the US environmental stressors of both nutrient surpluses and water resource depletion. Such patterns of environmental consequences are primarily driven by China's retaliation on US soybeans. Additional environmental stresses imposed on the United States could also be affected by the extent of China's retaliation on non-soybean oilseeds (Supplementary Fig. 7). Brazil would reduce its nitrogen surplus and blue water demand through crop mix changes but face an aggravated phosphorus surplus issue. China would experience limited environmental improvements. Globally, trade-offs exist among nitrogen surplus reduction, increases in phosphorus surplus, increases in blue water demand and increased harvested area.

Sensitivity analyses. While the environmental stressor evaluation in this study adopts standard Global Trade Analysis Project (GTAP) parameters and uses crop-specific environmental stressor intensity databases from reliable sources ${ }^{13,33,34}$, uncertainties in these parameters and data could affect the outcomes of the evaluation. To test the robustness of the evaluation outcomes, we designed the following sensitivity analyses focusing on these two major sources of uncertainties.

Regarding the uncertainties associated with the GTAP-BIO model, we first identified parameters to which the production portfolios are most sensitive, varied these parameters by $50 \%$ following an independent triangular distribution and obtained the consequent crop portfolio variations $s^{35}$. We then evaluated the resulting variations in global and regional environmental stressors by assuming that crop-specific environmental stressor intensity in each region remained unchanged (see Supplementary Information, section 7 for the rationale for the selection of parameters and the 50\% variation). We found that even with $50 \%$ variations, parameter uncertainties did not alter the direction of changes in environmental stressors. The environmental consequences in the United States and Brazil are most sensitive to soybean's trade elasticity and cropland transformation, while China is mostly affected by its protein preferences for animal feed (Supplementary Table 9).

Concerning the uncertainties in crop-specific environmental stressor intensity, we varied each major crop's intensity of nitrogen surplus, phosphorus surplus and blue water demand following independent triangular distribution. We then assessed the corresponding variations in global and regional environmental stressors by assuming constant average harvested area changes (changes reported in Fig. 3a). We found that the coefficient of variation for each environmental stressor is linearly related to the intensity variation level (Supplementary Table 10). Regional nitrogen surplus changes are more sensitive to the accuracy of the nitrogen surplus intensity estimate for soybean and other coarse grains, and the United States is most sensitive to its estimate of blue water demand intensity for soybeans, other coarse grains and sugar crops (Supplementary Table 10). Hence, potential variations in the data could also moderately weaken or amplify the conclusions made in this analysis but would not change the direction of patterns.

Local hotspots with additional environmental stresses. Heterogeneous distributions of crops and varying crop mixes and RUEs in crop production at subnational scales cause divergence of the local environmental stress changes from the aggregate national changes (Fig. 4). Unique crop portfolios in each grid cell could lead to spatial trade-offs and synergies within each environmental stressor and across different environmental stressors. To investigate the heterogeneous consequences on a subnational scale, we downscaled the modelling results from GTAP for each AEZ to $30 \times 30$ arcminute grids, following the approach that has been applied in multiple 

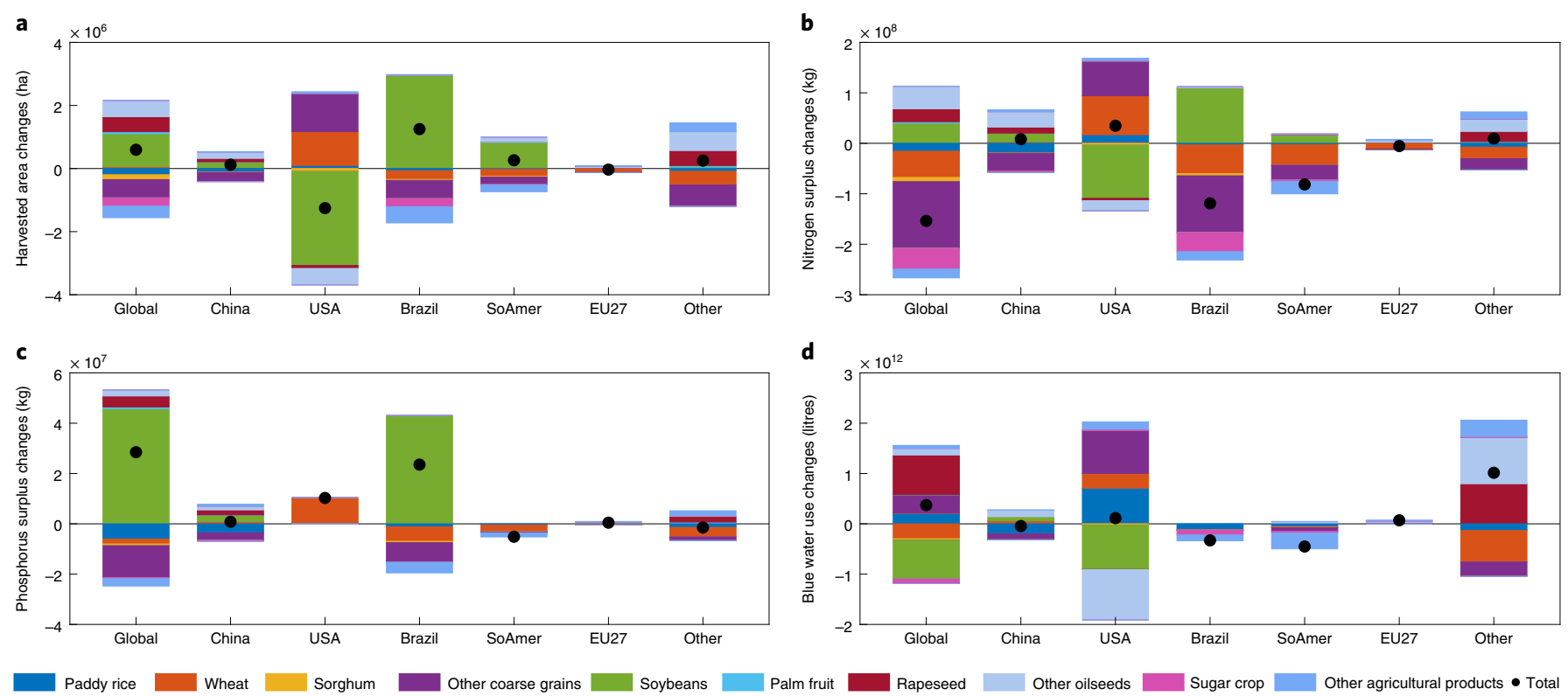

Fig. 3 | Changes in environmental stresses. a-d, Changes in environmental stresses by region and crop type: harvested area (ha) (a), total nitrogen surplus (kg) (b), total phosphorus surplus ( $\mathrm{kg}$ ) (c) and total blue water demand (litres) (d). In each bar, total changes are denoted by black dots, which are further decomposed into contributions from changes in each crop type represented by coloured blocks. The leftmost bar summarizes total global changes and the contributions from each crop type.

studies $^{34,36,37}$. The downscaled results represent one of the plausible changes in crop distribution and subsequent changes in intensities of nitrogen surplus, phosphorus surplus and blue water demand on a subnational scale under the trade tension and based on the model structure and assumptions.

China's retaliation on US agriculture would lead to the contraction of soybean production mainly in the US soybean/corn belt where the production of other coarse grains expands-resulting in a reduction in total nitrogen surplus (Supplementary Fig. 6b) but an increase in nitrogen surplus intensity for this region (Fig. 4a). The expansion of other coarse grains is much less than the reduction in soybean production, leading to the decline of harvested area for the region. However, because other coarse grain has a higher nitrogen surplus intensity than soybean, the intensity of nitrogen loss increases on the remaining cropland (Fig. 4a). The expansion of wheat would focus on the northern and western regions of the midwestern United States, accompanied by increasing phosphorus surplus intensity. Such phosphorus surplus intensity increase is aggravated by further expansion of wheat production. With the increasing tariffs imposed on all crops, the northwestern United States would experience a reduction in nitrogen surplus reduction as other coarse grains produced in the midwest substitute those produced in this region. Meanwhile, the contraction of nitrogen-efficient non-soybean oilseeds in southern regions would aggravate local nitrogen surplus intensity but relieve local demands for blue water. However, if the non-soybean oilseeds are not retaliated, soybean reduction could potentially incentivize their production in southern regions, reducing local nitrogen surplus intensity (Fig. 4a) but demanding more blue water (Fig. 4c).

In contrast to the contraction in the United States, soybean would expand in South America mainly in the central-west and southern regions of Brazil and the northeastern regions of Argentina. While adding pressures on land use changes in these areas, the expansion of soybean production may relieve nitrogen surplus intensity and blue water demand intensity by replacing wheat, other coarse grains, sugar crops and other agricultural products. Consistent with national-scale analysis, the Brazilian soybean production area may experience aggravated phosphorus surplus intensity but other South American countries would benefit from lower phosphorus surplus intensity due to their different soil types (Fig. 4b).

Considering all three environmental stressors together, China's retaliatory tariffs would lead to the worsening of one or more environmental stresses in most regions (Fig. 4d). The region with reduced environmental stresses is mainly concentrated in southeast and northeast China, where soybeans and rapeseeds expand at the cost of other resource-intensive crops, and Argentina, where soybean production is incentivized. The rest of China is dominated by intensified blue water demand, while some regions would face increased nitrogen surplus (green areas in Fig. 4d for China) and phosphorus surplus intensity as well (purple areas in Fig. 4d for China). It is notable that $8.3 \%$ of the regions in China where crop production is incentivized would face challenges from aggregations of all three environmental stressors (brown areas in Fig. $4 \mathrm{~d}$ for China). Most regions in the midwestern, southern and northeastern United States are dominated by increases in nitrogen surplus and blue water demand intensity (green areas in Fig. $4 \mathrm{~d}$ for United States), as part of soybean production shifts to other crops with more intensive nitrogen surplus and/or blue water demand. Northern parts of the western United States show modest intensifying nutrient surpluses, and southern areas of the western United States have slight intensification in nitrogen surplus but intensified blue water demand if non-soybean oilseeds would not be retaliated (Supplementary Fig. 8). The Brazilian Amazon region faces the situation of intensified nutrient losses and blue water demands of existing agricultural practices as a result of a reduction in resource use efficient crops in crop mixes. Since total harvested area devoted to crop production in the Brazilian Amazon is relatively low (less transparent brown areas in Fig. 4d for Brazil), changes in the environmental stressors analysed here may be less of a concern, although any cropland expansion in the Amazon region would probably be important regarding other conservation issues. The rest of Brazil, where the crop production is more active, is dominated by intensified phosphorus fertilizer use and phosphorus losses in soybean-intensive areas. 


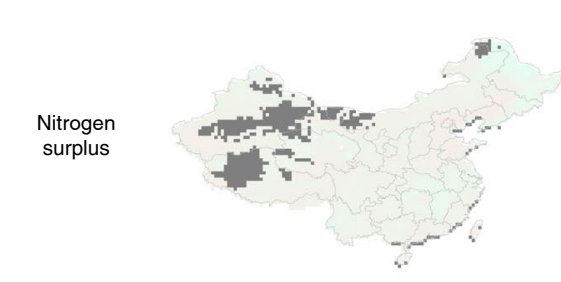

b

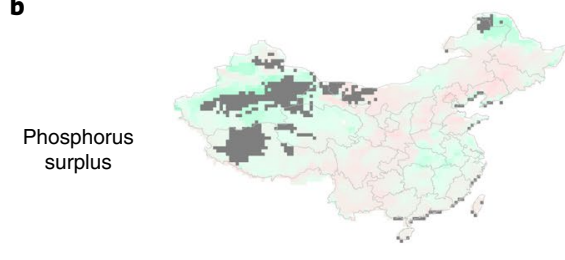

c

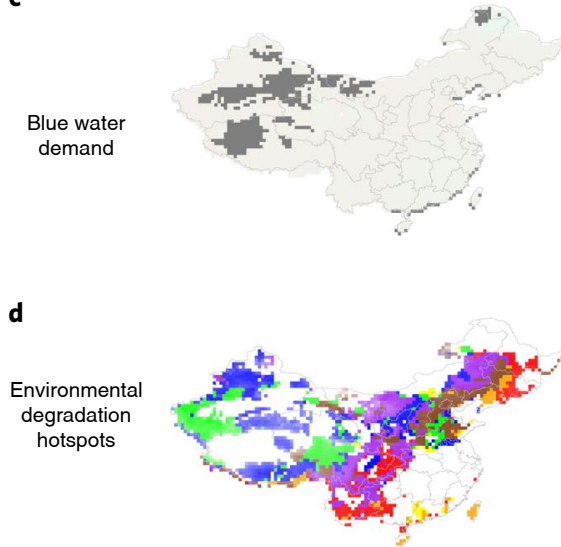

Contiguous USA
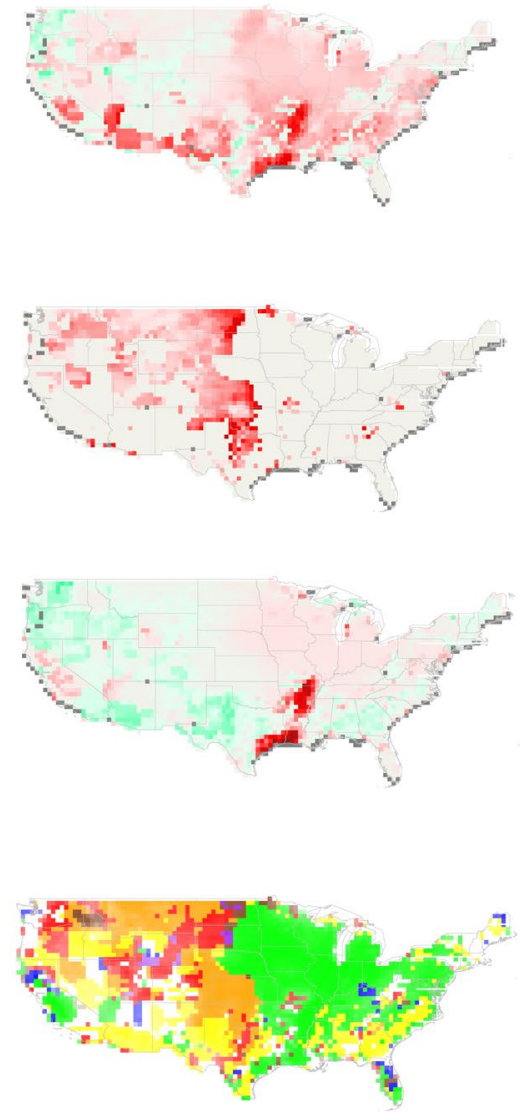

South America

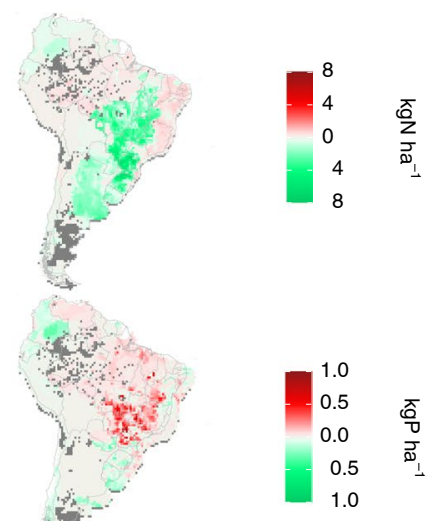

$2 e+05$

$1 \mathrm{e}+05$

0 ₹ $1 \mathrm{e}+05$
$2 \mathrm{e}+05$

\section{Environmental}

No cropland/no degradation nitrogen

Surplus only

Phosphorus surplus only

Blue water only

Nitrogen and phosphorus surplus

Nitrogen surplus and blue water

Phosphorus surplus and blue water

Nitrogen and phosphorus surplus and blue water

Fig. 4 | Changes in nitrogen surplus, phosphorus surplus and blue water demand intensity across different regions in China, the contiguous United States and South America. a-c, Changes in environmental stressors due to China's potential trade policy on US agricultural products: gridded nitrogen surplus $\left(\mathrm{kgNha}^{-1}\right)(\mathbf{a})$, phosphorus surplus $\left(\mathrm{kgPha}^{-1}\right)(\mathbf{b})$ and blue water demand $\left(\mathrm{lha}^{-1}\right)(\mathbf{c})$. d, Combining the three environmental stressors shows the hotspots of increased environmental degradation. The transparency of each grid cell denotes the logarithmic form of the total harvested area in ha where high transparency corresponds to high quantities of harvested area, and low transparency corresponds to low quantities of harvested area. For example, the Brazilian Amazon has low harvested area and thus is less transparent.

\section{Discussion}

Implications for future policy. The environmental consequences of crop trade need to be factored into decision-making on trade policy. Our analyses suggest that most of the environmental consequences come from the extent of China's retaliation on US soybeans (Supplementary Information, section 9). In contrast, China's retaliation on non-soybean crops would not alter the US nitrogen and phosphorus surplus changes, while the retaliation on non-soybean oilseeds would mitigate US blue water demand due to the contraction of these oilseeds, which are water demanding. Current trade negotiations are underway, and actual tariffs imposed on US agricultural products are subject to sudden changes during the process of the negotiation. The policymakers could use the analyses presented here to take into account the synergies and trade-offs between economic impacts and environmental stresses. These environmental stressors have been monetized in other studies to estimate the costs of alleviating pollution within acceptable levels ${ }^{16,38,39}$. However, the existing studies lack extensive global environmental valuations, which will require future research.

Although nutrient pollution and blue water consumption are primarily localized, international agricultural trade globalizes these environmental stresses, not only within the partner countries but also through spillover impacts on other countries. The assessments of environmental consequences of international trade across various spatial scales provide critical information for facilitating international conversations on mitigating nutrient pollution and relieving water shortages. While intergovernmental efforts have been made to collectively address climate change, much less has been done to coordinate efforts to mitigate nutrient pollution and water scarcity, which also have global-scale impacts (for example, $\mathrm{N}_{2} \mathrm{O}$ emissions are associated with nitrogen surplus and contribute to climate change and stratospheric ozone depletion ${ }^{40}$ ). The cross-scale environmental stress evaluations in this analysis offer policymakers an additional lens for addressing global environmental challenges in trade policy negotiations and international collaborations.

The varying impacts of trade policy on subnational scales highlight the need to improve the capacity for policymakers to project environmental degradation hotspots and to develop strategies to mitigate the negative impacts accordingly. Our analysis presents an initial attempt to downscale the impacts of trade policy change on a gridded level, highlighting the regions that will be negatively affected by increasing tariffs and their major environmental concerns. Although the downscaling approach has uncertainties, as discussed below, the results demonstrate the complex trade-offs among regions and environmental stresses and demonstrate the opportunities to develop strategies to minimize the negative socialenvironmental outcomes of trade policy changes. While the effects of international trade discussed here are important, it also needs 
to be recognized that the sustainability of agricultural production is affected by many socioeconomic and ecological drivers beyond trade, and improvements in agricultural technologies and practices are still fundamental for achieving sustainable agriculture.

Limitations. This paper only considers counterfactual situations of US agricultural products being retaliated given the economic situation in 2016 and subsequent proposed tariffs. Uncertainties evolve as new events affect China's demands, the US-China trade relationship and trade relationships of the United States and China with other countries. For example, US subsidies to farmers that compensate their price losses have potentially delayed their responses to the US-China trade tension ${ }^{40}$. The ongoing African swine fever harms China's pork supply and spurs its demands from overseas, such as the United States, potentially mitigating tariff impacts on pork producers but aggravating the US environmental stresses due to the demand for livestock feed. The rise of double-cropping practices in Brazil could potentially increase Brazil's crop productivity and RUEs. Such efficiency improvement could reduce pressures on some Brazilian environment and natural resources, but also could lead to the rebound effects from rising demands from overseas (for example, China) resulting in further environmental degradation and increases in cropland use pressures. China's ethanol mandates may increase China's corn production, reducing its soybean supply and alleviating its retaliation impacts on US soybeans. Meanwhile, China's Belt and Road Initiatives could help it find new agricultural partners, which could potentially exaggerate the impacts on US agriculture of China's retaliation and shift environmental impact to developing countries. The ongoing COVID-19 pandemic makes international trade more costly. The environmental and economic impacts on the weakening US-China trade relationship could thus be amplified. In addition, as China has been increasingly viewed as a threat to the United States' global economic and political power, China is likely, for national food security reasons, to seek options to reduce its reliance on agricultural imports from the United States ${ }^{41}$, which aligns with the trade scenario examined in this study. Overall, these events and future uncertainties may affect the crop production portfolios in China and around the world and consequently affect environmental stresses worldwide. Although examining the effects of these events is beyond the scope of this study, we provided methodologies for future investigation.

While tracing the fate of nitrogen and phosphorus surplus and blue water demand to specific environmental impacts-such as aquatic eutrophication, water quantity and quality, air pollution or greenhouse gas emissions-is beyond the scope of this paper, the environmental stressors of nitrogen and phosphorus surplus and blue water demand analysed here are likely to result in eventual environmental impacts. In addition, environmental consequences resulting from trade policies are not limited to nutrient pollution and blue water demand. Although we found that US-China agricultural trade tension could relieve nitrogen surplus and blue water demand in South America, additional pressures on cropland expansion could potentially lead to pastureland contraction and deforestation, aggravating emissions of greenhouse gases ${ }^{19-21}$ and reducing biodiversity and other ecosystem services. The resulting livestock reduction in the United States due to China's retaliation on its processed meat and dairy products could also alleviate US nutrient pollution and greenhouse gas emissions. South America's environment could also benefit from a livestock reduction driven by an expansion of harvested area and a contraction of pastureland. Incentivizing China's domestic livestock production, in contrast, could aggravate the country's environmental stresses. Although land use change, biodiversity loss and greenhouse gas emissions are beyond the scope of this analysis, they are additional environmental stressors that merit further study.
In addition to the market-mediated responses considered in this analysis, fertilizer application practices and blue water demand through irrigation are also likely to be impacted by market prices. For example, farmers may use more fertilizers when their prices are lower, resulting in decreased fertilizer use efficiency and greater nutrient surpluses. In this analysis, we assume the fertilizer application and water demand rate by each crop type in each region remains at the average level in 2014-2016, which could also be subject to change affected by market-mediated price signals. RUE could also improve with technological changes. However, with technology unchanged, market-response variations in nutrient surplus rate may not be very different from this analysis.

Gridded-level analyses are based on linear extrapolation from 2000 gridded crop production data to the average of 2014-2016 gridded harvested area data according to each crop's national growth rate. Such analyses could benefit from more recent gridded crop production data with detailed crop categories and ongoing development in evaluating and constraining uncertainties in nitrogen surplus maps. In addition, this analysis assumes that crops will expand in regions where they are historically grown, whereas crops could also expand to adjacent grids that have suitable climate and soil conditions. Gridded and regional analyses could also be further improved with detailed country specifications in the South American region, which is highly aggregated in current datasets.

Concluding remarks. This analysis evaluates the impacts of crop trade policies on environmental stressors-specifically nitrogen and phosphorus surpluses and blue water demand-from subnational to global scales due to shifts in crop mixes. We found that potential environmental consequences driven by the US-China crop trade tension are considerable and could spill over to other countries, especially Brazil and other South American countries through international trade. Such consequences are predominantly driven by China's proposed retaliation on US soybeans. Trade-offs and synergies exist across different countries for each type of environmental stressors and among different environmental stressors within each country. Overall, however, modelled effects of tariffs resulted in increased global environmental stresses. Additionally, spatial synergies and trade-offs occur within each country due to heterogeneous distributions of crop production. Environmental degradation hotspots were identified with one or more environmental stressors. These analyses provide a basis for consideration of environmental consequences in addition to the economic outcomes of current and future trade policies.

\section{Methods}

GTAP model. The GTAP model is a global multiregional and multisectoral model built upon computable general equilibrium theories. The GTAP model captures market-mediated responses through economic theories of supply, demand, trade and macroeconomic equilibrium relationships, considering behaviours from different economic entities, producers, consumers and government. It tracks changes in production, consumption and trade of all goods and services produced across the world, including agricultural products that are mostly exported from the United States to China: soybeans, fruits and vegetables, other oilseeds, processed food, forest products, processed non-ruminant meat, rapeseed, processed ruminant meat, beverages and sugar, sorghum, processed dairy products and soybean oil. Decisions of all entities are driven by relative price levers that are potentially changed by external interventions, such as policies. Bilateral trade flows link all economies, and changes in one economy will affect its partners and thus spill over to the globe. The GTAP model follows the Armington assumption that the same imported crop is differentiated based on its origins ${ }^{42}$. Imported and domestic crops are substitutable among private, industrial and government consumption.

In this analysis, we adopt a modified version of the GTAP extension: GTAP-BIO $^{3}$. This version consists of six regions: the United States, the European Union (27 states), Brazil, China, other South American countries and other regions. This geographical aggregation concentrates on the key regions that could be affected by China's tariffs on US agricultural products. Land endowments in the model are categorized into 18 AEZs. Harvested area changes driven by market-mediated responses can be tracked by AEZ in each region with a consideration of physical limits-crops can only expand in areas where they were 
historically grown. The model has ten crop types: paddy rice, wheat, sorghum, corn and other coarse grains, soybeans, palm fruit, rapeseeds, other oilseeds, sugar crops and other agricultural products. The model considers three types of land cover: cropland, pastureland and forest. Three types of land cover can be transformed into each other to some extent, with total land within each region/AEZ remaining constant. The model also takes account of crop-rotation practices as reported in Taheripour and Tyner ${ }^{43}$. In addition to land endowments, labour and capital endowments are also considered in producers' decisions. A detailed description of the GTAP model and GTAP-BIO is available in Supplementary Information, section 1.

Scenario design. In the main analysis, we implemented tariff increases that China proposed to impose on US agriculture in December 2019 (Table 1) ${ }^{44}$, which is the largest ever proposed by China on US agricultural products. Since the tariff increase primarily affects crops that are intensively traded with China, we only consider agricultural products being retaliated with bilaterally traded values from the United States to China greater than US\$100 million in 2016. Although not fully implemented, additional tariffs were imposed and the situation remains fluid. In addition, in Supplementary Information, section 9, we show a scenario in which only soybean is retaliated at the tariff rate proposed in December 2019 (the first row of the last column in Table 1). The soybean-only scenario aids the understanding of the important role that soybean plays in affecting the environmental consequences in China, the United States and South America.

Crop-specific environmental stressors by region. This analysis considers three environmental stressors: nitrogen surplus, phosphorus surplus and blue water demand. Nitrogen surplus and phosphorus surplus, the nitrogen and phosphorus lost to the environment, are defined as the differences between nitrogen (or phosphorus) inputs and nitrogen (or phosphorus) outputs (equation (1)). Nitrogen inputs include all nitrogen sources applied to crops including nitrogen from fertilizer, manure, agricultural biological nitrogen fixation and deposition. Nitrogen outputs refer to nitrogen harvested in crop products ${ }^{13,45}$. Phosphorus inputs are phosphorus from fertilizers and manure. Phosphorus outputs are phosphorus harvested in crop products. We use nitrogen surplus and phosphorus surplus as proxies of nutrient stressors of the environment from agricultural activities. Total nitrogen surplus and phosphorus surplus are measured in $\mathrm{kg}$.

$$
\mathrm{N}(\text { or } \mathrm{P}) \text { surplus }(\mathrm{kg})=\mathrm{N}(\text { or } \mathrm{P}) \text { inputs }(\mathrm{kg})-\mathrm{N} \text { (or P outputs })(\mathrm{kg})
$$

Nitrogen (or phosphorus) surplus intensity is nitrogen (or phosphorus) surplus $(\mathrm{kg})$ per hectare of harvested area (equation (2)).

$$
\mathrm{N}(\text { or } \mathrm{P}) \text { surplus intensity }\left(\mathrm{kg} \mathrm{ha}^{-1}\right)=\frac{\mathrm{N}(\text { or } \mathrm{P}) \text { surplus }(\mathrm{kg})}{\text { harvested area }(\mathrm{ha})}
$$

NUE or PUE is defined as the ratio between nitrogen (or phosphorus) outputs and nitrogen (or phosphorus) inputs (equation (3)).

$$
\mathrm{NUE}(\text { or PUE })=\frac{\mathrm{N}(\text { or } \mathrm{P}) \text { outputs }(\mathrm{kg})}{\mathrm{N}(\text { or } \mathrm{P}) \text { inputs }(\mathrm{kg})}
$$

Here water use refers to blue water-the surface and ground water potentially used for irrigation ${ }^{34,46}$. Total blue water demand is measured in litres. The water demand intensity rate is total blue water demand (litres) per ha of harvested area. Blue water demand efficiency is total product outputs $(\mathrm{kg})$ per litre of water.

The environmental stressor intensity database composes 169 crops and 218 regions. We aggregate them into ten crop types and six regions corresponding to the GTAP model. The classification of 169 crops to these ten crop types can be found in Supplementary Information, section 2. We use an average of 2014-2016 as the base year.

Alternative environmental stresses. Alternative environmental stresses in Fig. 2 refer to the environmental stresses that would have occurred if China's imported crops from the United States were entirely produced domestically or in alternative regions, assuming their respective RUEs and assuming adequate resources and suitable climate and soil conditions at alternative regions $i$. Alternative environmental stress is a hypothetical and counterfactual concept widely used in evaluating the RUEs of traded crops and the potential environmental stress that foreign demand could impose on local agricultural production ${ }^{15}$. Alternative harvested area (equation (4)), nitrogen surplus and phosphorus surplus (equation (5)) follow the calculation in Huang et al. ${ }^{15}$, and alternative blue water demand is calculated as imported crops in $\mathrm{kg}$ divided by blue water use efficiency $\left(\mathrm{kgl}^{-1}\right)$ at alternative regions (equation (6)).

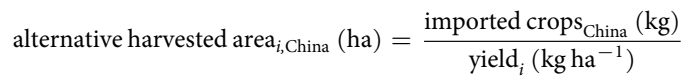

$$
\begin{aligned}
& \text { alternative } \mathrm{N} \text { (or P) } \text { surplus }_{i, \text { China }}(\mathrm{kg}) \\
& =\mathrm{N}(\text { or P }) \text { imported crops } \text { China }_{(\mathrm{kg})}\left(\frac{1}{\mathrm{NUE}(\text { or PUE })}-1\right)
\end{aligned}
$$

$$
\text { alternative blue water }{ }_{i, \text { China }}(\mathrm{kg})=\frac{\text { imported crops }(\mathrm{kg})}{\text { blue water use efficiency }\left(\mathrm{kg} \mathrm{l}^{-1}\right)}
$$

Gridded data analyses. Gridded harvested area data for 175 crops in the year 2000 at $5 \times 5$ arcminute level were obtained from EARTHSTAT ${ }^{47}$ and were mapped into 169 crops and aggregated into $30 \times 30$ arcminute grid cells. The EARTHSTAT map is employed over other state-of-art crop distribution maps (that is, $\mathrm{SPAM}^{48}$ ), because it has more disaggregated crop categories that have a one-to-one correspondence to most of our crop-specific and region-specific environmental stressor intensity database, yielding more plausible results on nutrient surplus distribution ${ }^{49}$. We linearly extrapolated each crop's harvested area from 2000 to the average of the 2014-2016 level based on their national growth rate following Houlton et al. ${ }^{36}$. The downscaling approach assumes that: (1) each crop type has the same environmental stressor intensity per ha of harvested area across all local areas in each country (or region); (2) for all grid cells within an AEZ of a country, the crop expansion rate for each crop type is the same as that of the AEZ; and (3) the expansion will stay within the grid cells within the same AEZ and will not spill over to adjacent cells across different AEZs. Changes in harvested area and environmental stressor intensities are first evaluated based on 169 crops and in 218 countries and then mapped into ten crop types and six regions.

Reporting summary. Further information on research design is available in the Nature Research Reporting Summary linked to this article.

\section{Data availability}

Nitrogen surplus intensity rate and phosphorus surplus intensity rate were derived following Zhang et al. ${ }^{13}$, using the data from FAOSTAT ${ }^{33}$. Blue water demand intensity rate was calculated using the blue water footprint provided by Mekonnen and Hoekstra ${ }^{34}$ and yield and harvested area data from FAOSTAT ${ }^{33}$. Gridded data on crop distribution were downloaded and processed using the database Harvested Area and Yield for 175 Crops year 2000 from EARTHSTAT provided by Monfreda et al. ${ }^{47}$. GTAP database version 9 was used in this analysis and updated from the base year 2011 to the year 2016 by Taheripour and Tyner ${ }^{3}$. Tariff increase data were obtained from the CARD trade tariff database ${ }^{44}$. The data used to generate the main figures in this paper are available in the Supplementary Information. The intermediate data that support the findings of this study are available from the corresponding author upon reasonable request. Source data are provided with this paper.

\section{Code availability}

Codes used to calculate the environmental stressor intensity and visualize the results are available at https://github.com/yaoguolin/SAM-CMT.

Received: 29 January 2020; Accepted: 8 July 2021; Published online: 12 August 2021

\section{References}

1. Major US Agricultural Export Markets: China, Canada, and Mexico (Farm Credit Administration, 2018); https://www.fca.gov/template-fca/download/ MajorUSAgriculturalExportMarkets.pdf

2. UN Comtrade Database (UN Comtrade, 2019).

3. Taheripour, F. \& Tyner, W. E. Impacts of possible Chinese $25 \%$ tariff on US soybeans and other agricultural commodities. Choices 33, 1-7 (2018).

4. Marchant, M. A. \& Wang, H. H. Theme overview: US-China trade dispute and potential impacts on agriculture. Choices 33, 1-3 (2018).

5. Qu, S. et al. Midwest Crop Farmers' Perceptions of the US-China Trade War (2019); https://www.card.iastate.edu/products/policy-briefs/display/?n=1294

6. The People's Republic of China (Office of the US Trade Representative, 2019); https://ustr.gov/countries-regions/china-mongolia-taiwan/peoplesrepublic-china

7. Irrigation Water Use (United States Geological Survey, 2019); https://www. usgs.gov/special-topic/water-science-school/science/irrigation-wateruse?qt-science_center_objects=0\#qt-science_center_objects

8. Water for Sustainable Food and Agriculture: A Report Produced for the G20 Presidency of Germany, 27 (Food and Agriculture Organization, 2017); http://www.fao.org/3/a-i7959e.pdf

9. Mateo-Sagasta, J., Marjani Zadeh, S. \& Turral, H. Water Pollution from Agriculture: A Global Review, 29 (Food and Agriculture Organization, 2017); http://www.fao.org/3/a-i7754e.pdf

10. Magdoff, F. \& van Es, H. (eds) in Building Soils for Better Crops: Sustainable Soil Management 4th edn Ch. 19 (Sustainable Agriculture Research \& Education, 2009).

11. Nutrient Pollution (Environmental Protection Agency, 2019); https://www.epa gov/nutrientpollution/issue

12. Peel, J. L., Haeuber, R., Garcia, V., Russell, A. G. \& Neas, L. Impact of nitrogen and climate change interactions on ambient air pollution and human health. Biogeochemistry 114, 121-134 (2013). 
13. Zhang, X. et al. Managing nitrogen for sustainable development. Nature 528, 51 (2015).

14. Matsuyama, K. Agricultural productivity, comparative advantage, and economic growth. J. Econ. Theory 58, 317-334 (1992).

15. Huang, G. et al. The environmental and socioeconomic trade-offs of importing crops to meet domestic food demand in China. Environ. Res. Lett. 14, 094021 (2019)

16. Sobota, D. J., Compton, J. E., McCrackin, M. L. \& Singh, S. Cost of reactive nitrogen release from human activities to the environment in the United States. Environ. Res. Lett. 10, 025006 (2015).

17. Yao, G., Hertel, T. W. \& Taheripour, F. Economic drivers of telecoupling and terrestrial carbon fluxes in the global soybean complex. Glob. Environ. Change 50, 190-200 (2018).

18. Galloway, J. N. et al. International trade in meat: the tip of the pork chop. Ambio 36, 622-629 (2007).

19. Fuchs, R. et al. Why the US-China trade war spells disaster for the Amazon. Nature 567, 451-454 (2019).

20. Richards, P., Taheripour, F., Arima, E. \& Tyner, W. E. Tariffs on American soybeans and their impact on land use change and greenhouse gas emissions in South America. Choices 35, 316-2020-1051 (2020).

21. $\mathrm{Du}, \mathrm{M}$. et al. Winners and losers of the Sino-US trade war from economic and environmental perspectives. Environ. Res. Lett. 15, 094032 (2020).

22. Lassaletta, L. et al. Food and feed trade as a driver in the global nitrogen cycle: 50-year trends. Biogeochemistry 118, 225-241 (2014).

23. Oita, A. et al. Substantial nitrogen pollution embedded in international trade. Nat. Geosci. 9, 111 (2016).

24. Shi, Y., Wu, S., Zhou, S., Wang, C. \& Chen, H. International food trade reduces environmental effects of nitrogen pollution in China. Environ. Sci. Pollut. Res. 23, 17370-17379 (2016).

25. Liu, J., Hertel, T. W., Taheripour, F., Zhu, T. \& Ringler, C. International trade buffers the impact of future irrigation shortfalls. Glob. Environ. Change 29, 22-31 (2014)

26. Taheripour, F., Hertel, T. W. \& Ramankutty, N. Market-mediated responses confound policies to limit deforestation from oil palm expansion in Malaysia and Indonesia. Proc. Natl Acad. Sci. USA 116, 19193-19199 (2019).

27. Itakura, K. Evaluating the impact of the US-China trade war. Asian Econ. Pol. Rev. 15, 77-93 (2020).

28. Li, M., Balistreri, E. J. \& Zhang, W. The US-China trade war: tariff data and general equilibrium analysis. J. Asian Econ. 69, 101216 (2020).

29. Gale, F. Development of China's Feed Industry and Demand for Imported Commodities FDS-15K-01 (US Department of Agriculture, 2015); http://www ers.usda.gov/publications/fds-feedoutlook/fds-15k-01.aspx

30. USDA Announces Details of Support Package for Farmers (United State Department of Agriculture, 2019).

31. Roy, E. D. et al. The phosphorus cost of agricultural intensification in the tropics. Nat. Plants 2, 16043 (2016).

32. Riskin, S. H. et al. The fate of phosphorus fertilizer in Amazon soya bean fields. Philos. Trans. R. Soc. Lond. B Biol. Sci. 368, 20120154 (2013).

33. FAOSTAT Statistics Database (Food and Agriculture Organization, 2018).

34. Mekonnen, M. M. \& Hoekstra, A. Y. The green, blue and grey water footprint of crops and derived crop products. Hydrol. Earth Syst. Sci. 15, 1577-1600 (2011).

35. Horridge, M. \& Pearson, K. Systematic Sensitivity Analysis with Respect to Correlated Variations in Parameters and Shocks (2011); https://www.gtap. agecon.purdue.edu/resources/res display.asp?RecordID $=3496$

36. Houlton, B. Z. et al. A world of cobenefits: solving the global nitrogen challenge. Earths Future 7, 865-872 (2019).

37. Siebert, S. \& Döll, P. Quantifying blue and green virtual water contents in global crop production as well as potential production losses without irrigation. J. Hydrol. 384, 198-217 (2010).

38. Kanter, D. R., Zhang, X. \& Mauzerall, D. L. Reducing nitrogen pollution while decreasing farmers' costs and increasing fertilizer industry profits. J. Environ. Qual. 44, 325-335 (2015).
39. Johansson, R. C. \& Randall, J. Watershed abatement costs for agricultural phosphorus. Water Resour. Res. 39, 1088 (2003).

40. Eagle, A. et al. Quantifying on-farm nitrous oxide emission reductions in food-supply chains. Earths Future 8, e2020EF001504 (2020).

41. US Farm Exports to China Hit Record-Hog Herders Snapup Soybeans, Corn. Arkansas Democrat-Gazette (9 December 2020).

42. Armington, P. S. A theory of demand for products distinguished by place of production. Staff Papers 16, 159-178 (1969).

43. Taheripour, F. \& Tyner, W. E. Biofuels and land use change: applying recent evidence to model estimates. Appl. Sci. 3, 14-38 (2013).

44. Li, M. CARD Trade War Tariffs Database Report (Center for Agriculture and Rural Development, 2018); https://www.card.iastate.edu/china/trade-war-data

45. Zhang, X. et al. Quantifying nutrient budgets for sustainable nutrient management. Glob. Biogeochem. Cycles 34, e2018GB006060 (2020).

46. Dalin, C., Wada, Y., Kastner, T. \& Puma, M. J. Groundwater depletion embedded in international food trade. Nature 543, 700 (2017).

47. Monfreda, C., Ramankutty, N. \& Foley, J. A. Farming the planet: 2. Geographic distribution of crop areas, yields, physiological types, and net primary production in the year 2000. Glob. Biogeochem. Cycles 22, GB1022 (2008).

48. Yu, Q. et al. A cultivated planet in 2010-Part 2: The global gridded agricultural-production maps. Earth Sys. Sci. Data 12, 3545-3572 (2020).

49. Kaltenegger, K. \& Winiwarter, W. Global gridded nitrogen indicators: influence of crop maps. Global Biogeochem. Cycles 34, e2020GB006634 (2020).

\section{Acknowledgements}

The authors acknowledge the support of the National Science Foundation Innovations at the Nexus of Food, Energy and Water Systems programme (grant number 1739823), and National Socio-Environmental Synthesis Center (SESYNC) under funding received from the National Science Foundation DBI-1639145. This publication was partially funded by the support of the Illinois Soybean Association, the Missouri Soybean Association, the Nebraska Soybean Board, the Ohio Soybean Council and their member farmers through Purdue (grant number 40002214) provided by the National Biodiesel Board, and the US Federal Aviation Administration Office of Environment and Energy through ASCENT, the FAA Center of Excellence for Alternative Jet Fuels and the Environment, ASCENT project (number 107208) through FAA Award [number 13-C-AJFE-PU] under the supervision of A.L. Oldani. Any opinions, findings, conclusions or recommendations expressed in this material are those of the authors and do not necessarily reflect the views of the FAA. The authors acknowledge the insightful suggestions provided by the late Dr W. E. Tyner. The authors also express special thanks to the four anonymous reviewers' invaluable and constructive comments.

\section{Author contributions}

G.Y. conducted all analyses in this research and drafted the paper. X.Z. supervised the work and contributed environmental insights. E.A.D. revised the paper and provided environmental insights. F.T. contributed the GTAP model. All authors edited, reviewed and approved the final manuscript.

\section{Competing interests}

The authors declare no competing interests.

\section{Additional information}

Supplementary information The online version contains supplementary material available at https://doi.org/10.1038/s43016-021-00338-1.

Correspondence and requests for materials should be addressed to G.Y. or X.Z.

Peer review information Nature Food thanks Jintai Lin, Wendong Zhang and the other, anonymous, reviewer(s) for their contribution to the peer review of this work.

Reprints and permissions information is available at www.nature.com/reprints.

Publisher's note Springer Nature remains neutral with regard to jurisdictional claims in published maps and institutional affiliations.

(c) The Author(s), under exclusive licence to Springer Nature Limited 2021 


\section{Reporting Summary}

Nature Research wishes to improve the reproducibility of the work that we publish. This form provides structure for consistency and transparency in reporting. For further information on Nature Research policies, see our Editorial Policies and the Editorial Policy Checklist.

\section{Statistics}

For all statistical analyses, confirm that the following items are present in the figure legend, table legend, main text, or Methods section.

n/a Confirmed

Х $\square$ The exact sample size $(n)$ for each experimental group/condition, given as a discrete number and unit of measurement

Х $\square$ A statement on whether measurements were taken from distinct samples or whether the same sample was measured repeatedly

Х The statistical test(s) used AND whether they are one- or two-sided

Х $\square$ Only common tests should be described solely by name; describe more complex techniques in the Methods section.

Х $\square$ A description of all covariates tested

Х $\square$ A description of any assumptions or corrections, such as tests of normality and adjustment for multiple comparisons

$\varnothing \square$ A full description of the statistical parameters including central tendency (e.g. means) or other basic estimates (e.g. regression coefficient)

$\bigotimes \square$ AND variation (e.g. standard deviation) or associated estimates of uncertainty (e.g. confidence intervals)

$\bigotimes \square \begin{aligned} & \text { For null hypothesis testing, the test statistic (e.g. } F, t, r \text { ) with confidence intervals, effect sizes, degrees of freedom and } P \text { value noted } \\ & \text { Give } P \text { values as exact values whenever suitable. }\end{aligned}$

\ $\square$ For Bayesian analysis, information on the choice of priors and Markov chain Monte Carlo settings

Х $\square$ For hierarchical and complex designs, identification of the appropriate level for tests and full reporting of outcomes

\ $\square$ Estimates of effect sizes (e.g. Cohen's $d$, Pearson's $r$ ), indicating how they were calculated

Our web collection on statistics for biologists contains articles on many of the points above.

\section{Software and code}

Policy information about availability of computer code

Data collection Collected data is processed using MATLAB R2018a

Data analysis Environmental stresses data was processed through MATLAB R2018a. Gridded crop distribution data was extracted using Python 3.7.0 package tifffile and processed using numpy and pandas. Environmental stresses on a gridded level were also processed using MATLAB R2018a. National level analyses were visualized using MATLAB R2018a. Gridded maps were generated using R version 3.5.3 with the packages: maptools, rgeos, rgdal, sf, ggplot2, raster, and RColorBrewer. GTAP results were run through GEMPACK release 11.4 and RunGTAP 3.7.0.. Sensitivity analyses with respect to parameters are conducted using RunGTAP 3.7.0., and sensitivity analyses with respect to environmental intensity data are analyzed using MATLAB R2018a.

For manuscripts utilizing custom algorithms or software that are central to the research but not yet described in published literature, software must be made available to editors and reviewers. We strongly encourage code deposition in a community repository (e.g. GitHub). See the Nature Research guidelines for submitting code \& software for further information.

\section{Data}

Policy information about availability of data

All manuscripts must include a data availability statement. This statement should provide the following information, where applicable:

- Accession codes, unique identifiers, or web links for publicly available datasets

- A list of figures that have associated raw data

- A description of any restrictions on data availability

National level raw data is available from FAOSTAT [http://www.fao.org/faostat/en/\#data]. All data sources of environmental stresses are available in the paper. The gridded level crop distribution data is available from EARTHSTAT [http://www.earthstat.org/]. The GTAP data version 9 is available from The Center for Global Trade 


\section{Field-specific reporting}

Please select the one below that is the best fit for your research. If you are not sure, read the appropriate sections before making your selection.
Life sciences
Behavioural \& social sciences
$\bigotimes$ Ecological, evolutionary \& environmental sciences

For a reference copy of the document with all sections, see nature.com/documents/nr-reporting-summary-flat.pdf

\section{Ecological, evolutionary \& environmental sciences study design}

All studies must disclose on these points even when the disclosure is negative.

Study description Quantitative analysis

Research sample This study focused on four major focal regions: China, the United States, Brazil, and Other South American countries. The data source can be found at the Data Availability Statement section.

Sampling strategy N/A

Data collection This study used existing datasets.

Timing and spatial scale The base year is the average of 2014-2016. The gridded level analyses is based on 30 by 30 arcmins.

Data exclusions N/A

Reproducibility N/A

Randomization N/A

Blinding N/A

Did the study involve field work? $\square$ Yes $\$ No

\section{Reporting for specific materials, systems and methods}

We require information from authors about some types of materials, experimental systems and methods used in many studies. Here, indicate whether each material, system or method listed is relevant to your study. If you are not sure if a list item applies to your research, read the appropriate section before selecting a response.

Materials \& experimental systems

\begin{tabular}{l|l}
\hline $\mathrm{n} / \mathrm{a}$ & Involved in the study \\
$\square$ & $\square$ Antibodies \\
$\square$ & $\square$ Eukaryotic cell lines \\
$\searrow$ & $\square$ Palaeontology and archaeology \\
$\square$ & $\square$ Animals and other organisms \\
$\square$ & $\square$ Human research participants \\
$\square$ & $\square$ Clinical data \\
$\square$ & $\square$ Dual use research of concern
\end{tabular}

\author{
Methods \\ $\mathrm{n} / \mathrm{a}$ Involved in the study \\ \ $\square$ ChIP-seq \\ Х $\square$ Flow cytometry \\ \ $\square$ MRI-based neuroimaging
}

